\title{
ATTITUDINAL MEANING IN MARTIN LUTHER KING JR SPEECH: A FUNCTIONAL GRAMMAR APPROACH
}

\author{
${ }^{1}$ Azka Saeful Haq*, ${ }^{1}$ Lia Maulia Indrayani, ${ }^{1}$ Ypsi Soeria Soemantri \\ ${ }^{1}$ Universitas Padjajaran, Indonesia \\ *Corresponding Author: azka19001@mail.unpad.ac.id
}

\begin{abstract}
Racial injustice becomes a primary issue in Martin Luther King Jr's entitled I have a dream in facing United States social condition. The speech reflects evaluative values to share perspectives toward the issue that can be analyzed by the appraisal system. The use of language certainly constructs different aims in evaluative language, and subjective presence is the target of evaluation in the appraisal system. The subjectivity of Martin Luther King Jr toward racial issues contains various types that can indicate a strategy to persuade people. The objectives of this study are to investigate the evaluative language of Martin Luther King Jr and to infer the meaning of evaluative language use. The strategy of delivering motivational messages is also discussed after acquiring the types of attitudes that will be related to the social issue. The research method employed in this study is descriptive qualitative. Systemic functional linguistic theory pioneered by Halliday and his colleagues becomes the framework in this study, and the tool is an appraisal system pioneered by J.R. Martin to analyze data. There are 90 clauses that consist of 33 judgement, 32 appreciation, and 26 affect. Judgement as the most dominant type reflects the reality of racial injustice to persuade many people to reject the condition. The strategy of critic conveyed in different types of attitudes can share deep messages to many people who listen. The result is hoped to be additional references in revealing speech strategy by using an appraisal system. The study of the appraisal system is useful to observe the subjectivity involvement in every form of language use.
\end{abstract}

Keywords: Appraisal System; Attitude; Evaluative Language; Interpersonal Meaning; Racial issue

\begin{abstract}
ABSTRAK
Ketidakadilan ras merupakan isu utama pada pidato berjudul 'I have a dream' oleh Martin Luther King Jr dalam menghadapi kondisi sosial Amerika Serikat pada masanya. Pidato ini menunjukan nilai-nilai evaluatif dalam berbagi pandangan yang dapat dianalisis menggunakan sistem appraisal terhadap isu rasial. Penggunaan bahasa mengonstruksi tujuan berbeda dalam bahasa evaluatif. Adanya subjektifitas merupakan target evaluasi dalam sistem appraisal. Subjektifitas Martin Luther King Jr terhadap isu rasial memiliki tipe tipe beragam yang dapat mengindikasikan strategi untuk membujuk orang. Tujuan riset ini adalah untuk menyelidiki bahasa evaluatif and menyimpulkan makna dari bahasa Martin Luther King Jr tersebut. Strategi penyampaian pesan yang menggerakkan juga didiskusikan setelah diperoleh tipe-tipe sikap (attitude) yang akan dikaitkan dengan isu sosial. Metode riset yang digunakan merupakan kualitatif deskriptif. Teori linguistik fungsional sistemik yang dirintis oleh Halliday menjadi kerangka teori pada riset ini dan alat analisisnya adalah sistem appraisal yang dirintis oleh J.R. Martin. Terdapat 90 klausa yang mengandung 33 tipe judgement, 32 tipe appreciation, dan 26 tipe affect. Tipe judgement sebagai tipe paling dominan mencerminkan kenyataan ketidakadilan ras untuk membujuk banyak orang dalam menolak kondisi tersebut. Strategi kritik yang disampaikan dalam tipe berbeda dapat memberikan pesan pesan mendalam untuk banyak orang yang mendengarkan. Hasil riset diharapkan dapat menjadi referensi tambahan dalam
\end{abstract}


Celtic: A Journal of Culture, English Language Teaching, Literature and Linguistics

Vol. 7, No. 1, June 2020.

E-ISSN: 2621-9158 P-ISSN:2356-0401

http://ejournal.umm.ac.id/index.php/celtic/index

mengungkap strategi pidato melalui pemanfaatan sistem appraisal. Studi sistem appraisal berguna untuk mengamati keterlibatan subjektifitas dalam setiap bentuk penggunaan bahasa.

Kata Kunci: Attitude; Bahasa Evaluatif; Isu Rasial; Makna Interpersonal; Sistem Appraisal

\section{INTRODUCTION}

The subjectivity of someone towards social phenomena around him can be revealed by investigating his own word choices related to appraised things (Martin and Rose:2005). The use of language certainly constructs different aims in evaluative language that has particular aims behind itself. Subjective presence is the target of evaluation, and how someone interacts provides interpersonal meaning that can be investigated by appraisal analysis. There is no neutral position for evaluative words with their tendency, so the result of evaluative language use is the positive or negative value. Someone conveys and implies his feelings and value towards social phenomena to achieve his aims. It can be aimed at persuading, convincing, influencing, or the other different negotiations in social interactions.

Martin Luther King Jr as an influential leader in the United States concerns with social injustice of black men. His principles are conveyed by the provocative diction in his speech that refers to evaluative language. He rejects racial discrimination in the United States and uses his words to mobilize mass. It is the reason why this speech becomes legend, and it is discussed until now as evidence of citizenship rights struggle in America. The speech encompasses changes in ways of thinking that will further evoke new rights for black people in the social structure. The Washington Post becomes one of the media that still discusses Martin Luther King Jr's struggle entitled What would Martin Luther King Jr, Say about the Current Civil Unrest (1 June 2020). It contains the Black civil movement story, which refers to racism still found today.

This study deals with the racial injustice issue concerned by Martin Luther King $\mathrm{Jr}$ in his speech. His speech becomes the object of this study. How he arranged the words to influence the public is discussed in this study by identifying evaluative word choices. Clauses represent emotions of someone towards something and they become ideas to share in a social context. The clause that is treated as a manifestation of an activity involving people and things becomes the focus of analysis. Refusal of social injustice emerges in the speech related to the social condition of the United States in racism.

One of several previous studies is from Ulfah, Sujatna, and Amalia (2019) entitled attitudinal meaning in the syllabus of same-sex marriage legal document of the United States: a systemic functional linguistics approach. It contains clauses which are divided into 91 affects, 54 judgments, and 58 appreciations in attitude system and it does not discuss the engagement and graduation system. The result of that study tends to show that the word choice in attitude types, there are 'harm' and 'criminal' that most often in insecurity constituent. It tends to show to the reader that the petitioners want equality by saying that marriage is a fundamental right of all humans that must be obtained. So marriage must be legalized. The word choice in attitude types, there are 'fundamental' in valuation constituent and 'intimate' in normality constituent.

The other previous study is adopted from Rohmawati (2016) entitled appraisal 
Haq, A.S., Indrayani, L.M. \& Soemantri, Y.S. (2020). Attitudinal meaning in speech of Martin Luther King Jr: A Functional Grammar Approach. Celtic: A Journal of Culture, English Language Teaching, Literature, \& Linguistics, 7(1), 14-22.

devices realizing attitudes in Barack Obama's inaugural speech. It employs attitude system that reveals 51 Affects, 155 Judgements, and 117 Appreciations. The use of judgement in the speech dominates the percentage of attitudes. Obama uses positive attitudes more often than the negative ones in the speech. It indicates that Obama is a good leader with high capability and a great way of thinking.

The next previous research is gained from Ademilokun (2015) entitled aspects of attitudinal meaning in Nigerian President Muhammadu Buhari's inauguration speech: an appraisal analysis. It restricts the analysis only in the attitude system as well. The most dominant system as the result is affect. The analysis reveals that affective meanings are mostly employed in the speech to establish and maintain interpersonal. It is used by the President for the externalisation of his personal feelings, having contested the presidency unsuccessfully at three different times in the past and having undergone a mentally and sociologically sapping electioneering campaign experience.

The urgency of this study is reflected in the findings of linguistic evidence that represent a social critic in American society. The frequency of attitude types encompasses the inference to represent the subjectivity of Martin Luther King Jr toward conditions. The subjectivity of a public figure aims to influence his followers to acquire similar subjective emotions. Persuading the people to gain the same public opinions is one of the final purpose in delivering the speech.

\section{Interpersonal Meaning}

One of clause metafunction is interpersonal meaning constructed to enact in communication. To discuss social issue, clauses in the speech are viewed as the exchange in society. Halliday (2014) remarks that a clause has meaning as an exchange, a transaction between speaker and listener; the Subject is the warranty of the exchange. It is the element of the speaker to make responsible for the validity of what he is saying.

\section{Appraisal System}

Martin and Rose (2007) state that appraisal is concerned with evaluation, the kinds of attitudes that are negotiated in a text, the strength of the feelings involved and the ways in which values are sourced and readers aligned. Appraisal system can be employed to phonology, lexicogrammar, and discourse semantic relation, but in this study it is used for discourse semantic level. There are three interacting domains in appraisal system, namely 'attitude', 'engagement' and graduation,' but in this study, attitude system specifically becomes the focus.

Attitude is mostly conveyed by adjectives to give a positive or negative value."Attitude is concerned with our feelings, including emotional reactions, judgments of behavior and evaluation of things. Engagement deals with sourcing attitudes and the play of voices around opinions in discourse. Graduation attends to grading phenomena whereby feelings are amplified and categories blurred (Martin, 2005)"

\section{Attitude System}

The attitude system represents the evaluative entity in language use. Someone uses subjective presence to give values toward something. This system gives the result in a positive or negative value. The values can be represented by adjectives, adverbs, 
Celtic: A Journal of Culture, English Language Teaching, Literature and Linguistics

Vol. 7, No. 1, June 2020.

E-ISSN: 2621-9158 P-ISSN:2356-0401

http://ejournal.umm.ac.id/index.php/celtic/index

nouns, or verbs. Lipson (2006) states that Attitude concerns the values by which speakers/writers evaluate human behavior and objects and associate emotional/effectual responses with participants and processes.

Martin and White (2005) remark that attitudinal meanings tend to spread out and color a phase of discourse as speakers and writers take up a stance oriented to affect, judgement or appreciation. In this system, there are three subsystems that reveals specific meaning of a word. The types are affect, judgement, and appreciation.

\section{Affect}

This type of attitude reflects the emotion of emoter toward phenomena. It refers to the source of emotion which is represented by emoters. Emoter and its emotion cannot be discussed separately. The use of pronoun $I$ usually becomes the characteristic of this type. Painter (2003) remarks that emotion is arguably at the heart of these regions since it is the expressive resource we are born with and embody physiologically from almost the moment of birth. This subsystem has its types, and it contains three types of affect at least. They are happiness, security, and satisfaction in positive value.

\section{Judgement}

This system refers to evaluate behavior and characteristic of people as the target of evaluation. "Judgement deals with attitudes towards behavior, which we admire or criticize, praise, or condemn (Martin and White, 2005)." It contains the same feature as the other attitude system, such as positive and negative categories. In conveying the evaluations toward behavior, someone uses word choices to reflect judgement. The types of word class in judgement are adjective, noun, adverb, and verb.

\section{Appreciation}

This system connects to the mental process which refers to the conscious activity of someone. "Appreciations can be divided into our 'reactions' to things (do they catch our attention; do they please us?), their 'composition' (balance and complexity), and their 'value' how innovative, authentic, timely, etc.) (Martin and White, 2005)." Those three types of appreciation relate to human consciousness, namely feelings for emotions, five senses for composition, and cognition for valuation.

The appraisal system specific area of attitude system with affect, judgement, and appreciation subsystem becomes focus in this study related to the research questions that investigate and infer evaluative meaning. It is different with Ulfah, et al. (2019) that studies attitude system in law proposal and Rohmawati (2016) in the political context, this study relates to social discrimination issue behind racial injustice.

\section{METHOD}

The research method employed in this study is descriptive qualitative. In this study, the speech script is divided into clauses in minor or major form. The clauses are categorized into the types of attitude. To reduce data, clauses are selected to acquire the statements that relate to subjective presence. The data are not changed at all to gain valid criteria. The attitude clauses are counted to investigate the frequency of types assisted by AntConc software. Acquiring lexical choices to divide the subjective words that relate to personal emotions is assisted by concordance features of the software. 
Haq, A.S., Indrayani, L.M. \& Soemantri, Y.S. (2020). Attitudinal meaning in speech of Martin Luther King Jr: A Functional Grammar Approach. Celtic: A Journal of Culture, English Language Teaching, Literature, \& Linguistics, 7(1), 14-22.

After deciding the numerous subjective lexical words, the words are categorized based on the types of attitudes manually. The specific types of attitude clauses are found to determine the frequency. The frequency is meant after the most dominant type is found. SFL theory, namely interpersonal meaning pioneered by M.A.K Halliday and his colleague becomes the framework in this study and the tool to analyze is appraisal system pioneered by J.R Martin.

\section{FINDINGS}

The clauses that have been selected are analyzed by identifying the types of attitude as the first research question substance. As appraisal theory pioneered by J.R Martin and his colleagues, the clauses have been categorized into the types of attitude. Martin Luther King Jr as a representation of black men in the United States becomes the appraiser or person who is feeling toward the racial injustice issue. The trigger of emotion or what is appraised is the racial injustice issue. There are 90 clauses that contain values, but the findings are only the sample of each type.

Table 1. Findings of attitude elements in Martin Luther King Jr's speech

\begin{tabular}{|c|c|c|c|c|c|c|}
\hline \multirow{2}{*}{} & \multicolumn{5}{|c|}{ Attitude Systems } \\
\cline { 2 - 7 } & Affect & Judgement & \multicolumn{4}{c|}{ Appreciation } \\
\hline & Types & Frequency & Types & Frequency & Types & Frequency \\
\hline & Happiness & 3 & Normality & 3 & Reaction & 12 \\
\hline & Security & 4 & Capacity & 3 & Composition & 6 \\
\hline Negative (-) & Satisfaction & 4 & Propriety & 1 & Valuation & 3 \\
\hline & Unhappiness & 2 & Normality & 16 & Reaction & 5 \\
\hline & Insecurity & 5 & Capacity & 4 & Composition & 1 \\
\hline $\begin{array}{c}\text { Total of } \\
\text { Data }\end{array}$ & Dissatisfaction & 8 & Propriety & 7 & Valuation & - \\
\hline
\end{tabular}

Attitude as Affect

This type contains both positive and negative values with various subtypes, namely happiness, security, and satisfaction. The clauses with positive values are "I am happy to join with you today," "This is our hope," and "Thank God Almighty." Those clauses show that Martin gives positive responses, even the racial issue stimulates massive movement. As a leader, he tries not to provoke negatively, but he also reminds the peace of the audience or the readers. It can be seen from the diction above, which reflects positive responses.

The clauses with negative values are "The Negro is still languished in the corners of American society," "that some of you have come here out of great trials and tribulations," and "but one hundred years later, the Negro still is not free." Those clauses show that negative affect emerges as the dominant domain than the positive one it reflects the tendency to respond the racial issue negatively. The use of dictions referred was to convey the pain in the social world. 
Celtic: A Journal of Culture, English Language Teaching, Literature and Linguistics

Vol. 7, No. 1, June 2020.

E-ISSN: 2621-9158 P-ISSN:2356-0401

http://ejournal.umm.ac.id/index.php/celtic/index

\section{Attitude as Judgement}

This type contains both positive and negative values with various subtypes, namely normality, capability, and propriety. The clauses with positive values are "all men are created equal.", "my people who stand on the warm threshold which leads into the palace of justice," and "We must forever conduct our struggle on the high plane of dignity and discipline." Those clauses show what condition is proper. Even the dictions do not refer to negative entities, and Martin tends to convey the ideal condition.

The clauses with negative values are "now is the time to lift our nation from the quicksands of racial injustice to the solid rock of brotherhood, "as long as the Negro is the victim of the unspeakable horrors of police brutality," and "Some of you have come from areas where your quest for freedom left you battered by the storms of persecution and staggered by the winds of police brutality". Those clauses indicates that Martin reflects the reality of racial injustice to persuade many people to reject the condition. It can be seen from the dictions that represents injustice in America.

\section{Attitude as Appreciation}

This type contains both positive and negative values with various subtypes, namely reaction, composition, and valuation. The clauses with positive values are "This momentous decree came as a great beacon light of hope,", "The whirlwinds of revolt will continue to shake the foundations of our nation until the bright day of justice emerges," and "In the process of gaining our rightful place." Those clauses indicate the grateful responses in facing the condition. Even the racial issue comes as a big problem, Martin uses positive appreciation in his speech as the dominant domain than a negative one. It can be seen from the dictions that he has a hope to change the condition. Not only giving the negative comment, but he also spreads the hope that will exist.

The clauses with negative values are "So we have come here today to dramatize a shameful condition," "America has given the Negro people a bad check," and "will now be content will have a rude awakening." Those clauses reflect the condition transformed into other things. It indicates the disappointment in facing the non-ideal condition. The negative elements tend to declare the bad condition to change. 
Haq, A.S., Indrayani, L.M. \& Soemantri, Y.S. (2020). Attitudinal meaning in speech of Martin Luther King Jr: A Functional Grammar Approach. Celtic: A Journal of Culture, English Language Teaching, Literature, \& Linguistics, 7(1), 14-22.

Table 2. Frequency of attitude elements in Martin Luther King Jr's speech

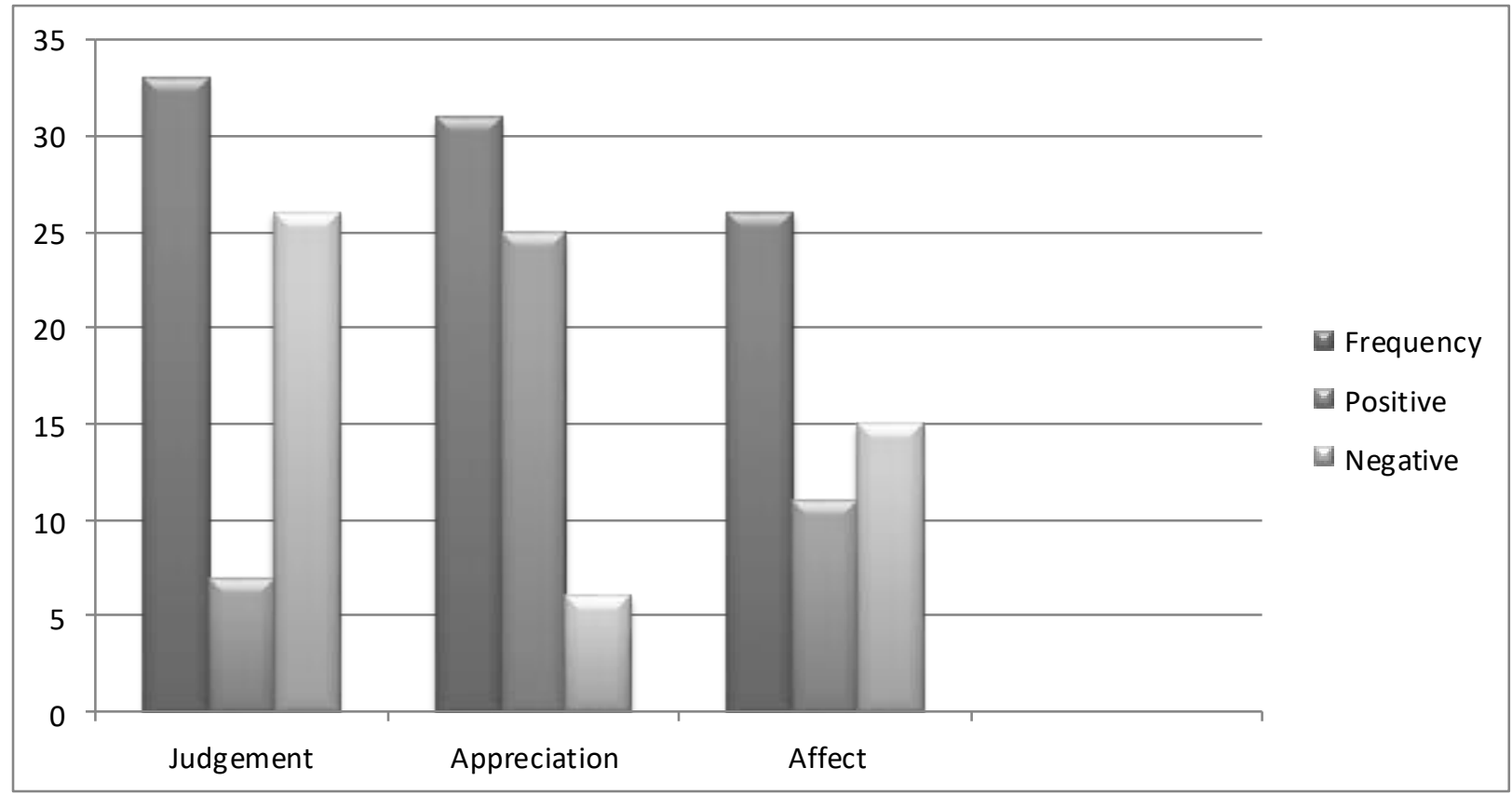

\section{DISCUSSION}

To answer both research questions, the frequency of all attitude types are interpreted based on findings. The frequency presented shows that speech of Martin Luther King has various attitude elements in conveying his evaluative language. Attitudinal meaning emerges in attitude system within its variety realized by clauses. The table informed by chart shows that judgement is the most dominant type of attitude element in facing racial injustice issue. It consists of 33 data and takes $37 \%$ in proportion. The word choices in judgement such as equal, true, violence, brutality, freedom, oppression, despair mostly reflect the refusal with most dominant negative type. The word choices in appreciation, such as rude, bad, great, obvious, bright, shameful, marvelous, reflect the hope to change the condition and take $34 \%$ proportion. The word choices in affect such as free, happy, joyous, languished, satisfied, guilty reflect the emotions and take $29 \%$ proportion.

Associating to racial injustice, those lexical choices reflect facts felt by Black people in that period. Racial injustice is rejected to maintain equality in civil rights through expressing and revealing discrimination in social real life. Judgement words represent injustice in social structure employed not only by goverment but also numerous society. The speech emerges to mark the Black existence as an equal man in American society. The contemplative messages in speech are the hope of Black in that period to a better future for the next Black generation. It is different with Rohmawati (2016) and $\mathrm{Su}$ (2016) that reflect positive and convincing findings, this study represents the refusal of social injustice toward the Black race through emphasizing predominant negative attitudes. 
Celtic: A Journal of Culture, English Language Teaching, Literature and Linguistics

Vol. 7, No. 1, June 2020.

E-ISSN: 2621-9158 P-ISSN:2356-0401

http://ejournal.umm.ac.id/index.php/celtic/index

\section{CONCLUSION}

The most frequent attitude reflected by judgement indicates that Martin Luther King tends to imply the necessity of change after conveying bad condition by using negative type. The gap between each attitude system is thin, which reflects the balance of sharing emotions. The negative emotions mix orally with positive emotions to persuade people. It can be inferred that negative emotion as the refusal of the condition, but positive emotions do not have to disappear. Negative emotions can be hatred that can stimulate revenge. Martin Luther King Jr responds to the racial injustice issue with mixed emotion in his speech. The strategy of critic conveyed in a different type of attitude can give deep messages to people who listen. Appreciation attitude is used positively to describe expected conditions analogized in something different. Affect attitude is used negatively to express the collective disappointed emotion of black man represented by Martin Luther King Jr. Because of its findings, this study can be a new reference to whom tends to arrange a similar study. The inference of linguistic evidence can also be a critic that maintains the legacy of Martin Luther King Jr.

\section{REFERENCES}

Demilokun, Mohammed.(2015).Aspects Of Attitudinal Meaning In Nigerian President Muhammadu Buhari's Inauguration Speech: An Appraisal Analysis. The African Symposium Volume 15, No. 2, December 2015. African :Obafemi Awolowo University

Halliday, M.A.K and Matthiessen.(2014).Halliday's Introduction to Functional Grammar (Fourth Edition). USA and Canada: Hooder Education

Kumalasari, Faradila and Soeparto.(2015).Factors Influencing The Motivation Of The Students F'rom Thailand In Choosing English Department In University Of Muhammadiyah Malang. Celtic: A Journal of Culture, English Language Teaching, Literature, \& Linguistics. Malang: University of Muhammadiyah Malang

Li, Xiaqing.(2016).An Attitudinal Analysis of English Song Discourse from the Perspective of Appraisal Theory. Journal of Language Teaching and Research, Vol. 7, No. 3, pp. 559-565, May 2016 Shanxi Normal University: China

Lipson, Maxine. (2006).Exploring Functional Grammar. CLUEB : Bologna

Martin, J. R.(2000). Beyond Exchange: Appraisal Systems in English. In Hunston, S. \& $\mathrm{G}$

Martin, J. R. and White, P. R. R.(2005).The Language of Evaluation, Appraisal in English. Palgrave Macmillan: US and UK

Martin, J. R. and Rose, David.(2007).Working with Discourse, Meaning Beyond the Clause. Continuum:London

Ngo, Thu and Unsworth, Len.(2011).Vietnamese Person Reference System as an Appraisal Resourse. Linguistic Diversity and Cultural Identity: a Global Perspective, 169-188. Nova Science Publishers, Inc.

Painter, C.(2003).Developing attitude: an ontogentic perspetive on Appraisal. Text 23.2. $183-210$.

Pascual, Mariana and Unger, Lidia.(2010).Appraisal in the Research Genres: an Analysis of Grant proposals by Argentinean Researchers. Network of Scientific Journals 
Haq, A.S., Indrayani, L.M. \& Soemantri, Y.S. (2020). Attitudinal meaning in speech of Martin Luther King Jr: A Functional Grammar Approach. Celtic: A Journal of Culture, English Language Teaching, Literature, \& Linguistics, 7(1), 14-22.

from Latin America, the Caribbean, Spain, and Portugal: Argentina.

Rohmawati.(2016).Appraisal Devices Realizing Attitudes In Barack Obama's Inaugural Speech. Jurnal Vision, Volume 5 Number 1, April 2016. Blora

Su, Ting.(2016).Positive Discourse Analysis of Xi Jinping's Speech at the National University of Singapore under Appraisal Theory.Shanxi Normal University: Linfen

Ulfah, Sujatna, and Amalia.(2019).Attitudinal meaning in the syllabus of same-sex marriage legal document of the United States: a systemic functional linguistics approach. Leksika Vol. 13, No.2, August 2019. Universitas Padjajaran: Bandung

Yang, Linxiu and Xiaojuan, LV.(2015).Reporting Evidentials in Generic Structures of English Research Articles-from the Perspective of Engagement in Appraisal System.International Journal of Linguistics and Communication 3 (1).American Research Instttute for Policy Development. 